\title{
Preeclampsia and donor oocyte pregnancy - case report
}

\section{Preeclampsia şi sarcina obținută prin donare de ovocite-prezentare de caz}

\author{
Oana Mihaela IORDACHE ${ }^{1}$, Erick George NEȘTIANU ${ }^{2}$, Maria Cristina PASĂRE ${ }^{1}$ \\ ${ }^{1}$ Spitalul Clinic „Filantropia“, Bucureşti, România \\ ¿Universitatea de Medicină şi Farmacie „Carol Davila“, Bucureşti, România
}

\begin{abstract}
The rising incidence of using reproductive technology in humans is followed by pregnancies at an advanced maternal age. Pregnancies achieved by reproductive technology are generally multiples pregnancies at ages over 40 years and they have a higher risk of developing preeclampsia, gestational diabetes and preterm birth.

We will present the case of a 44 years old patient who has a twin pregnancy achieved by egg donation who develop severe preeclampsia and gestational diabetes.
\end{abstract}

Keywords: preeclampsia, oocyte donation pregnancy, multifetal pregnancies

\section{REZUMAT}

Creşterea incidenței utilizării tehnicilor de reproducere umană asistată determină apariția sarcinilor la vârste din ce in ce mai avansate. Sarcinile obținute prin fertilizare in vitro sunt de obicei sarcini multiple ce apar la vârste avansate (peste 40 de ani) şi au un risc crescut de dezvoltare a preeclampsiei, diabetului gestațional şi naşterii premature. Prezentăm cazul unei paciente în vârstă de 44 de ani care a obținut o sarcină gemelară în urma unor proceduri de donare de ovocite şi care dezvoltă la 34 de săptămâni de sarcină preeclampsie severă şi diabet gestațional.

Cuvinte cheie: preeclampsie, donare de ovocite, sarcină multiplă

\section{INTRODUCERE}

În ultimii ani progresul tehnicilor de reproducere umană asistată a lărgit opțiunile valabile pentru femeile cu vârstă înaintată. Majoritatea sarcinilor obținute prin IVF sunt sarcini multiple apărute la vârste înaintate (> 40 ani) (1).

Indicația inițială pentru sarcina cu donare de ovocite (DE-IVF) a fost reprezentată de insuficiență ovariană prematură la femei cu vârsta mai mică de 40 de ani. Ulterior, indicațiile acestei proceduri s-au lărgit incluzând scăderea rezervei foliculare ovariene la femei cu ovare încă funcționale, eșecul repetat al procedurilor de fertilizare in vitro cu material genetic propriu și femeile care poartă anomalii genetice ce ar putea fi transmise produsului de concepție (1).

Trounson et al a raportat în 1983 prima sarcină obținută prin donare de ovocite; atât donatoarea cât și primitoarea au fost reprezentate de paciente cu lung istoric de infertilitate (2). Experimentul lui Trounson et al a fost prima încercare reușită la om, dar care a ridicat multiple probleme de etică.

Sarcinile obținute prin donare de ovocite sunt considerate sarcini cu risc atât datorită 
vârstei materne avansate, existenței sarcinii multifetale și, cel mai frecvent, nuliparității.

Incidența preeclampsiei (complicație redutabilă a sarcinii din cauza prognosticului matern și perinatal) în populația generală este de 3-4\%, crește la 5-10\% la gravidele cu vârsta peste 40 de ani și atinge $35 \%$ la gravidele cu vârsta de peste 50 (3). Sarcinile obținute prin donare de ovocite au un risc crescut de apariție a preeclampsiei (riscul este de 3-4 ori mai mare comparativ cu sarcinile obținute prin fertilizare cu material genetic propriu) (3-4). Rata de apariție a hipertensiunii arteriale cronice este 2-4 ori mai mare la femeile cu vârste peste 35 de ani comparativ cu grupul de vârstă 30-34 (5).

Apariția complicațiilor în sarcinile obținute prin fertilizare in vitro este multifactorială, fiind implicați factori precum: vârsta și fondul genetic matern (cele mai importante), caracteristici paterne, cauze ce determină infertilitatea, medicație utilizată, factori spermatici, medii de cultură și condiții de laborator (6).

\section{PREZENTARE CAZ}

Pacientă în vârstă de 43 de ani și 9 luni, cu infertilitate primară și 2 eșecuri de obținere a sarcinii prin fertilizare in vitro cu material genetic propriu efectuate după vârsta de 40 de ani, efectuează embriotransfer cu 2 embrioni de ziua 5 (blastocist) obținuți prin donare de ovocite de la o donatoare anonimă și fertilizate cu sperma partenerului, rezultând o sarcină gemelară cu 2 embrioni. Deși antecedentele medicale ale pacientei au fost nesemnificative, antecedentele heredocolaterale ale acesteia au atras atenția asupra dezvoltării preeclampsiei și diabetului zaharat la rudele de gradul I (sora și mama). Pacienta este consiliată asupra riscului de a dezvolta preeclampsie și diabet gestațional și sunt făcute recomandări cu privire la dietă și câștigul ponderal în sarcină.

Postembriotransfer pacienta primește tratament cu Utrogestan 800 mg/zi și Duphaston 10 mg/zi până în săptămâna 14 și acid acetilsalicilic 75 mg până la 17 săptămâni și ulterior 150 mg până la termen.

Ecografia de morfologie de trimestrul I și dublul test efectuate la 12 săptămâni vârstă gestațională stabilesc diagnosticul de sarcină gemelară biamniotică bicorială fără anomalii morfologice, cu un calcul de risc pentru anomalii cromozomiale în limite normale, dar cu estimarea riscului de naștere prematură de 1:15 și de preeclampsie de 1:10. Pentru estimarea riscului de preeclampsie s-au utilizat markeri biochimici și biofizici (Dopplere artere uterine). S-a considerat necesară începerea monitorizării tensiunii arteriale, măsurătorile din trimestrul I nedepășind valoarea de 125/90 mmHG la brațul stâng și 120/90 mmHG la brațul drept.

Fiind considerată o sarcină cu risc obstetrical crescut, pacienta a fost evaluată ecografic lunar. La 17 și 22 de săptămâni vârstă gestațională, curbele de creștere fetală prezentau un trend ascendent în conformitate cu curbele de creștere fetală pentru sarcina gemelară, cu instalarea și menținerea notch-ului bilateral pe arterele uterine și RI crescut pe artera uterină dreapta. La 26 săptămâni de gestație pacienta prezintă un câștig ponderal de $12 \mathrm{~kg}$, iar rezultatul testului de toleranță la glucoză cu 75 g glucoză pulvis stabilește diagnosticul de diabet gestațional (glicemia a jeun - $101 \mathrm{mg} / \mathrm{dl}$, glicemia la 1 oră $183 \mathrm{mg} / \mathrm{d}$, glicemia la 2 ore $-153 \mathrm{mg}$ ). Pacienta este îndrumată către consult de diabetologie cu modificarea dietei, control glicemic după fiecare masă și monitorizare zilnică a TA.

În ciuda monitorizării zilnice, la 32 săptămâni de gestație, pacienta se prezintă la camera de gardă pentru contracții uterine dureroase și cefalee, având valori tensionale la măsurători repetate consecutive de 160/90 mmHg, însoțite de creșterea transaminazelor (TGO $=67 \mathrm{U} / \mathrm{I}$, TGP $=89 \mathrm{U} / \mathrm{I})$ și proteinurie $(0,4 \mathrm{~g} / 24$ ore $)$. Se inițiază terapie antihipertensivă (Dopegyt 250 mgla 12 ore), tocoliză (Nifedipin) și corticoterapie (Dexametazonă $24 \mathrm{mg}$ fracționate în 4 doze la 12 ore) cu monitorizare atentă a glicemiei. Sub terapie susținută, valorile tensionale nu depășesc 135/90 mmHg, starea mamei și a fătului permițând externarea după 48 ore și continuarea tratamentului antihipertensiv la domiciliu.

Pacienta se reinternează la 34 săptămâni de gestație pentru cefalee, tulburări vizuale, trombocitopenie $(115.000 / \mathrm{mmc})$, creșterea transaminazelor (TGO = $234 \mathrm{U} / \mathrm{I}, \mathrm{TGP}=365 \mathrm{U} / \mathrm{I})$, tulburări de coagulare și valori tensionale de 190/110 $\mathrm{mmHg}$, situație care impune controlul tensiunii arteriale prin terapie antihipertensivă i.v. cu Ebrantyl și profilaxie anticonvulsivantă cu sulfat de magneziu. Evaluarea stării fetale prin examen ecografic și cardiotocografic indică alterarea stării unuia dintre gemeni (oligoamnios sever, raport cerebro-ombilical inversat cu undă $a$ absentă la velocimetria de duct venos, test de nonstres non reactiv), precum și lipsa de control eficient a tensiunii materne, impun nașterea de urgență prin operație cezariană (indicație preeclampsie severă și status fetal incert), extrăgându-se făt 1 
masculin, $1.800 \mathrm{~g}$, scor Apgar 6 la 1 minut și făt 2, masculin, $2.000 \mathrm{~g}$ cu scor Apgar 8 la 1 minut.

Postpartum, valorile tensionale materne se mențin în limite normale, necesitând doze minime de Metoprolol pentru controlul TA (100 $\mathrm{mg} / \mathrm{zi}$ ). Pacienta se externează după 14 zile de la naștere, iar la controalele de rutină de la 6 săptămâni și 6 luni postpartum valorile tensiunii arteriale și ale glicemiei au fost normale.

\section{DISCUȚII}

Sarcinile obținute la vârste avansate prin tehnici de reproducere umană asistată au mai multe complicații decât sarcinile obținute spon$\tan (8)$.

Există studii care au indicat că scăderea rezervei ovariene asociată cu scăderea responsivității ovarului la FSH determină modificări vasculare care ar putea fi implicate în fiziopatologia preeclampsiei (9). Sarcinile obținute prin donare de ovocite au un risc mai mare de a dezvolta preeclampsie (de 3-4 ori), diabet gestațional sau naștere prematură comparativ cu cele obținute prin fertilzare in vitro cu material genetic propriu (10).

Gravida cu sarcină obținută prin donare de ovocite este o gravidă cu risc înalt prin acumularea de factori de risc: vârstă, nuliparitate, sarcină multiplă și, în cazul prezentat, factori heredocolaterali (11).

Sarcinile obținute prin donare de ovocite au anumite particularități și sunt mai predispuse la apariția complicațiilor. Există mai multe teorii implicate în fiziopatologia preeclampsiei în sarcina obținută prin donarea de ovocite.

Alterarea invaziei trofoblastice și reducerea transformării endovasculare a arterelor spiralate determină preeclampsie prin ischemie (12).

Se consideră că apare o alterare a răspunsului imun de tip grefă-gazdă cu placentație anormală și răspuns imun inadecvat. Controlul răspunsului imun la implantarea unității feto- placentare (diferită genetic în totalitate de genomul matern) este una din marile provocări ale monitorizării acestor sarcini. Apare o interacțiune între antigenul HLA-C fetal și celulele materne natural killer. Prin intermediul celulelor natural killer se produc citokine ce mediază invazia trofoblastică a arterelor spiralate (13).

Insuficiența ovariană determină apariția de anticorpi ce ce ar putea interveni în invazia trofoblastică și ar determina preeclampsie (13).

Adminsitrarea de aspirină în doze mici preconcepțional ar putea îmbunătăți prognosticul procedurilor de reproducere umană asistată atît ca număr de sarcini obținute, cât și în reducerea riscului de preeclampsie (14).

Pacienta necesită consiliere înainte de efectuarea procedurilor pentru a fi conștientă de riscurile ce pot să apară.

La cazul prezentat mai sus s-a apelat la donarea de ovocite din cauza rezervei ovariene scăzute, vârstei înaintate și eșecului repetat IVF (2 proceduri fără rezultat). Pacienta a dezvoltat hipertensiune arterială indusă de sarcină cu preeclampsie severă și diabet gestațional.

\section{CONCLUZII}

Majoritatea gravidelor ce obțin sarcini în urma donării de ovocite sunt gravide cu comorbidități și necesită urmărire complexă în echipă multidisciplinară.

Principalele complicații ce pot să apară sunt preeclampsia, diabetul gestațional, nașterea prematură.

Gravida ce obține o sarcină prin donare de ovocite este considerată gravidă cu risc înalt de a dezvolta preeclampsie și necesită monitorizare în maternitate de grad trei pentru ameliorarea prognosticului matern și perinatal.

Adminsitrarea de acid acetilsalicilic atât preconcepțional, cât și în primele două trimestre de sarcină poate fi benefică.

Conflict of interest: none declared Financial support: none declared

\section{BIBLIOGRAFIE}

1. Sauer M.V., Kavic S.M. Oocyte and embryo donation; reviewing two decades of innovation and controversy.Reprod Biomed Online 2006;12:153

2. Trounson A., Leeton J., Besanko M.

Pregnancy established in an infertile patient after transfer of a donated embryo fertilised in vitro. Br. Med J 1983 286:835

3. Allen V.M., Wilson R.D., Cheung A.

Pregnancy outcomes after assisted reproductive technology. J.Obstet Gynaecol Can 2006; 28:220
4. Centers for Disease Control and Prevention. Assisted Reproductive Technology Reports and Resources

5. Luke B., Brown M.B. Contemporary risks of maternal morbidity and adverse outcomes with increasing maternal age and 
plurality. Fertil Steril 2007;

88-283

6. Krieg S.A., Henne M.B., Westphal L.M. Obstetric outcomes in donor oocyte pregnancies compared with advanced maternal age in in vitro fertilization pregnancies. Fertil Steril 2008; 90-65

7. Salha O., Sharma V., Dada T., Nugent D., Rutherford A.J., Tomlinson A.J. The influence of donated gametes on the incidence of hypertensive disorders of pregnancy.Hum Reprod 1999.

8. Sonderstom-Antilla V., Tiitien A., Foudila T., Hovatta O. Obstetrics and perinatal outcome after oocyte donation:comparison with in-vitro fertilization pregnancies. Hum Reprod 1998; 484-90

9. De Vos M., Devroey P., Fauser B.C. Primary ovarian insufficiency. Lancet 2010; 376:911-921

10. Pados G., Camus M., Van Steirghem A., Bonduelle M., Devroey P. The evolution and outcome of pregnancies from oocyte donation. Hum Reprod 1994 538-42

11. Krieg S.A., Henne M.B., Westphal L.M. Obstetric outcomes in donor oocyte pregnancies compared with advanced maternal age in in vitro fertilization pregnancies. Fertil Steril 2008; 90-65

12. Kauffman P., Black S., Huppertz B. Endovascular trophoblast invasion: implications for the pathogenesis of intrauterine growth retardation and preeclampsia. Biol Reprod 2003; 69:1-7

13. Kelkar R.L., Meherji P.K., Kadam S.S., Gupta S.K., Nandedkar T.D. Circulating auto-antibodies against the zona pellucida in women with premature ovarian failure. $J$. Reprod Immunol 2005:66:53-67

14. Groenveld E., Lambers M.J., Lambalk C.B. Preconceptional low dose aspirin for the prevention of hypertensive pregnancy complication and preterm delivery after IVF. Hum Reprod 2013; $28 ; 1480$. 